2. Terry W. Du Clos. Pentraxins: Structure, Function, and Role in Inflammation // ISRN Inflamm. 2013; 2013: 379040. Published online 2013 Sep 14. doi: 10.1155/2013/379040/

3. Рыболовлев Ю.Р. Дозирование веществ для млекопитающих по константам биологической активности [Текст] / Ю.Р. Рыболовлев, Р.С. Рыболовлев // Доклады АН СССР, 1979. Т. 247. № 6. С. 1513-1516.

4. Пат. 38911 UA, МПК (2009) G01N33/544. Спосіб визначення концентрації С-реактивного білка експрес-методом / В. В. Козар, М. Я. Кудря (UA); заявник і патентовласник ДУ «Інститут проблем ендокринної патології ім. В. Я. Данилевського АМН України» (UA). № u200810068; заявл. 04.08. 2008; опубл.26.01.2009 Бюл. № 2 - 6 с.

DOI https://doi.org/10.30525/978-9934-588-81-5-2.34

\title{
ВПЛИВ РАЦІОНУ $З$ НАДЛИШКОМ ПОЖИВНИХ РЕЧОВИН МАТЕРІВ НА СТРУКТУРНІ ЕЛЕМЕНТИ ТА ПОКАЗНИКИ ЖИРОВОГО ОБМІНУ СИРОВАТКИ КРОВІ ЇХНЬОГО ОДНОМІСЯЧНОГО ПОТОМСТВА
}

Кузнецова М. О.

асистент кафедри патологічної фізіології імені Д. О. Альперна Харківський начіональний медичний університет

Ніколаєва О. В.

доктор медичних наук, завідувач кафедри патологічної фізіології імені Д. О. Альперна Харківський національний медичний університет

Кузнецова I. К. асистент кафедри медичної біології Харківський національний медичний університет м. Харків, Україна

Хвороби органів травлення займають одне 3 провідних місць в структурі дитячої соматичної патології. Особливо турбує тенденція до зростання частки захворювань гепатобіліарної системи в структурі захворюваності та інвалідизації серед дитячого населення України. Серед чинників які можуть призводити до пошкодження печінки як матері так і плоду одне з головних місць належить раціону з надлишком поживних речовин [1]. Існує гіпотеза яка пов'язує розвиток пев- 
них захворювань з впливом внутрішньоутробних умов в яких перебуває плід [2]. За останні роки накопичилося багато даних про вплив надлишкових раціонів на морфофункціональний стан різних органів i систем, в тому числі і печінки невагітних самиць щурів та дуже мало про їхню дію в системі мати-плід. Це все обумовлює актуальність наших досліджень.

Метою цього дослідження було визначення впливу пренатального надлишку поживних речовин на морфофункціональний стан печінки одномісячного потомства.

Матеріали та методи. Дослідження проведено на потомстві щурів, отриманому від 13 рандомбредних самиць популяції WAG, 50\% яких становили групу контролю, інші протягом вагітності отримували раціон 3 надлишком жирів та вуглеводів входили в основну групу (2-а гр.). Потомство щурів обох груп отримувало базовий раціон віварію та виводилось 3 експерименту через 1 місяць після народження шляхом декапітації. Морфофункціональний стан печінки оцінювали за результатами імуногістохімічного дослідження (ІГХ) (визначались маркери пошкодження ендотелію судин: ендотеліальна синтаза оксиду азоту (eNOS) і індуцибельна синтаза оксиду азоту (iNOS)) [4] та за біохімічним дослідженням сироватки крові. В сироватці визначали вміст загального холестерину (заг. ХС), тригліцеридів (ТГ), ліпопротеїдів високої щільності (ЛПВЩ), ліпопротеїдів низької та дуже низької щільності (ЛПНЩ, ЛПДНЩ), індексу атерогенності (IA). Рівень заг. ХС, ТГ, ЛПВЩ визначали спектрофотометричним методом за допомогою реактивів фірми «Ольвекс» (Росія), а ЛПНЩ та ЛПДНЩ, IА - розрахунковим методом [3].

Всі експерименти на тваринах виконувались відповідно до правил та міжнародних рекомендацій Свропейської конвенції щодо захисту хребетних тварин, які використовуються для експериментів або 3 іншою науковою ціллю (Страсбург, 1986). Статистична обробка результатів проводилася 3 використанням програми GraphPadPrism5. Для визначення достовірності відмінностей застосовували U критерій Манна-Уітні.

Результати. При IГХ - дослідженні у 1-місячних щурят 2-ї гр. фарбування печінки 3 eNOS демонструвало помірну переривчасту реакцію синусоїді, які були збережені, серед дистрофічних гепатоцитів, а також злущення ендотеліальної вистілки центральних вен і судин портальних трактів, вогнищеве накопичення eNOS спостерігалось у стромі портальних трактів; iNOS визначалась в ендотелії центральних вен та прилеглих до них гепатоцитах. Це все вказувало на незначний 
ступінь ушкодження ендотелію судин печінки одномісячного потомства щурів 2-ї гр.

Визначення ліпідного спектру крові у одномісячних щурят 2-ї гр. виявляло зниження вмісту ТГ і загального ХС - на 17,0\% (p<0,001) i $11,4 \%$ ( $<0,0001)$ відповідно. У ліпідограмі відзначається істотне зниження рівня ЛПВЩ - на 47,9\% ( $<0,0001)$ та підвищення вмісту ЛПНЩ - на $73,4 \%(\mathrm{p}<0,0001)$, а це не дивлячись на зниження рівня ЛПДНЩ - на $18,5 \%(\mathrm{p}<0,0001)$, призводило до значного збільшення IA - на 212\% ( $<0,0001)$. Такі дані свідчать про помірне пошкодження ліпідного обміну печінки одномісячного потомства 2-ї гр. Характер виявлених структурно-функціональних змін може бути пов'язаним 3 включенням механізмів епігенетичного програмування у потомства яке пренатально перебувало в умовах надлишку поживних речовин та дозволяє стверджувати наявність ризику розвитку ожиріння, метаболічного синдрому та іншої органічної патології.

Висновки. Отже, враховуючи отримані результати досліджень можливо зробити висновок про помірний ступінь пошкодження печінки одномісячного потомства щурів, які знаходилися в умовах пренатального надлишку поживних речовин, який можна розцінювати як фактор ризику розвитку різноманітної органічної та функціональної патології печінки в майбутньому.

\section{Література:}

1. Звягинцева ТД, Чернобай АИ. Хронические заболевания печени. Одесса; 2011: 256 с.

2. Lee HS. Impact of maternal diet on the epigenome during in utero life and the developmental programming of diseases in childhood and adulthood. Nutrients. 2015; 7(11): 9492-507.

3. Камышников ВС. Методы клинических лабораторных исследований. Москва: «Медипресс - информ»; 2016: 736 с.

4. Марковський ВД, Сорокіна II, Гольєва НВ, Купріянова ЛС. Гістологічна, гістохімічна і імуногістохімічна техніки: Навчальний посібник для бакалаврів. - Харків: ХНМУ, 2011: 152 с. 